\title{
Gonadossomatic relation and reproductive strategy of Brycon opalinus (Cuvier, 1819) in the Serra do Mar State Park - Núcleo Santa Virgínia, Atlantic Forest, Brazil
}

\author{
Gomiero, LM.* and Braga, FMS. \\ Departamento de Zoologia, Instituto de Biociências, Universidade Estadual Paulista - UNESP, \\ CP 199, CEP 13506-900, Av. 24-A, n. 1515, Rio Claro, São Paulo, Brazil \\ *e-mail: leanmg@rc.unesp.br
}

Received November 23, 2005 - Accepted May 10, 2006 - Distributed November 30, 2007

(With 5 figures)

\begin{abstract}
The objective of this study was to analyze the gonadossomatic relation of males and females of Brycon opalinus (the Pirapitinga do Sul) in the Serra do Mar State Park-Núcleo Santa Virgínia. The study area included three rivers: Paraibuna, Ipiranga, and Grande. From the gonadossomatic relation, it was possible to determine the reproductive season and strategy of this species. The gonadossomatic relation was high throughout the year for both males and females. Sperm competition and dilution of the ejaculate in the spawning locations favored substantial development of the testicles. The sex ratio of Brycon opalinus was always in favor of females. The existence of sexual dimorphism in this species was confirmed from the larger size of the females.
\end{abstract}

Keywords: Brycon opalinus, gonadossomatic relation, reproductive strategy, Brazil.

\section{Relação gonadossomática e estratégia reprodutiva de Brycon opalinus no Parque Estadual da Serra do Mar - Núcleo Santa Virgínia, Mata Atlântica, Brasil}

\begin{abstract}
Resumo
O objetivo deste estudo foi o de analisar a relação gonadossomática de machos e fêmeas de Brycon opalinus (Pirapitinga do Sul) no Núcleo Santa Virgínia - PESM. A área de estudo abrangeu três rios (Paraibuna, Ipiranga e Grande). Com este parâmetro foi possível determinar a época e a estratégia reprodutiva para esta espécie. A RGS foi alta durante o ano tanto para machos quanto para fêmeas. A competição de esperma e a diluição da ejaculação nos locais de desova acarretaram o grande desenvolvimento dos testículos. A proporção sexual de Brycon opalinus sempre foi maior para as fêmeas e o dimorfismo sexual da espécie foi constatado devido ao maior tamanho das fêmeas.
\end{abstract}

Palavras-chave: Brycon opalinus, relação gonadossomática, estratégia reprodutiva, Brasil.

\section{Introduction}

Teleost fishes show the greatest variation of gonadal structure compared to other vertebrate groups (Srivastava and Sinch, 1994).

The gonadossomatic relation (GSR) expresses the percentage which the gonads represent of the total weight of an individual, and is an efficient indicator of the functional state of the gonads (Vazzoler, 1996). In addition, the GSR provides a basis for determining the period of greatest reproductive intensity, evidencing the reproductive strategy of each species. These strategies can vary within a species, and even within a sex, and may occur in most taxa (Gross, 1996). Alternative mating strategies are expected in the presence of strong sexual selection or when some males are excluded from mating (Gross, 1985; Vieites et al., 2004).

In aquatic environments, at the moment of mating, the gametes are liberated freely into the water and the proportion of the spawn that will be fertilized is strongly influenced by the number of spermatozoa and by the water movement (Denny and Shibata, 1989). Among fish with external fertilization, the number of spermatozoa may be very limited because of the rapid dilution of the sperm when it is liberated into the water, and because of this, the amount of sperm may be insufficient to fertilize all the oocytes deposited during mating (Levitan et al., 1995). The reproductive success of the males depends on their distance from the females, the presence or absence of a potential competitor, and on the current velocity (Levitan, 2005).

To increase the number of their descendents, the males can mate with several females, although the females in turnabout can mate with several males at the same time (polyandry) (Yasui, 1998). Several factors may lead to simultaneous polyandry, such as a high den- 
sity of males, explosive reproductive activity, and competition for egg-laying sites (Prado and Haddad, 2003). In such cases, there may be sperm competition (Yasui, 1998), which is defined as competition among sperm from two or more males to fertilize the eggs of a single female (Parker, 1970). Normally, when several males are involved in spawning, the quantity of sperm increases, facilitating fertilization of the female's oocytes (Zbinden et al., 2003).

The objective of the present study was to analyze the gonadossomatic relation (GSR) of males and females of Brycon opalinus (Cuvier, 1819) in three rivers of the Parque Estadual da Serra do Mar-Núcleo Santa Virgínia. From the GSR, it was possible to determine the breeding season and reproductive strategy of this species.

\section{Material and Methods}

A total of 12 samples were made monthly from January to December 2004. Each collection period lasted four days. Three sites in the Paraibuna basin were selected for the collections: the Paraibuna, Ipiranga, and Grande rivers. These sites are located within of the Santa Virgínia Unit of the Serra do Mar State Park (23 $24^{\circ}$ and $23^{\circ} 17^{\prime} \mathrm{S}$ and $\left.45^{\circ} 03^{\prime} \mathrm{W}\right)$. At each sample point, individuals were collected using gill nets with mesh sizes of $1.5 ; 2.0 ; 2.5 ; 3.0 ; 3.5$, and $4.0 \mathrm{~cm}$, measured between adjacent knots (10 $\mathrm{m}$ long and $1.5 \mathrm{~m}$ high), and totalizing $60 \mathrm{~m}$. In addition to the nets, sieves and traps were also used.

Fish effort was standardized, keeping time and the quantity of instruments employed at each point constant.

Each individual was measured: total length $(\mathrm{cm})$, total mass (g), testes or ovaries mass (g), and gonad maturation stage (Braga, 1990).

The maturation stage of each specimen was determined macroscopically, considering coloration, transparency, superficial vascularization, and, for ovaries, the visualization and appearance of the oocytes. In agreement with a previously established scale, four different maturation stages were considered: A: immature, B: in maturation, C: mature, and D: spent (Vazzoler, 1996).

The population structure was analyzed according to locality and period of collection, as to the variations in the proportion of the sexes (sex-ratio). The i $x 2$ type contingency table (where $\mathrm{i}>2$ ) was used for the sex-ratio analyses to the stages of maturity (B and C) at each collection point (Vanzolini, 1993).

According to Vazzoler (1996), the gonadossomatic relation is determined by the ratio between the weight of the gonad and the body weight of each specimen, multiplied by 100 (percentage). The means of these relationships were determined at each locality and stage of maturity for males, females, and immatures. The variations of the gonadossomatic relations of males and females in stage $\mathrm{C}$ (matures) according to period, collection locale, and length class are also presented.

\section{Results}

During the collecting period, 216 specimens of Brycon opalinus in three sites were analyzed.

The gonadossomatic relation for the immatures (stage A) of B. opalinus was low because of the lack of development of the gonads. For maturing individuals (stage B), males in the Ipiranga River showed the highest GSR. In mature individuals (stage C), males in the Grande River showed the highest GSR (8.13), the mean being 6.36. For females, the GSR was also highest in the Grande River (8.54), with a mean of 8.08. The GSR for spent individuals (stage D) was relatively low for males as well as for females in all three rivers (Table 1).

The analysis of the sex-ratio to the stage of maturity $\mathrm{B}$ (in maturation) indicated no difference $\left(\chi^{2}>0.05\right)$, but for mature males and females, it demonstrated that the females were always more numerous at all collection points $\left(\chi^{2}<0.05\right)$ and seasons of the year, except in Autumn for the Ipiranga River (Figure 1).

The highest GSR values were obtained for mature individuals (stage C). The GSR values for males as well as those for females were above $5 \%$ for all three collection points (Figure 2).

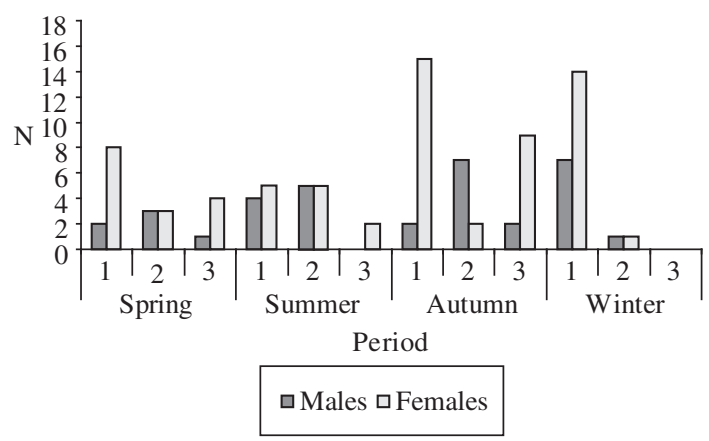

Figure 1. Numerical distribution of mature males and females of Brycon opalinus in each season of the year and at the three collection points (1. Paraibuna; 2. Ipiranga; and 3. Grande).

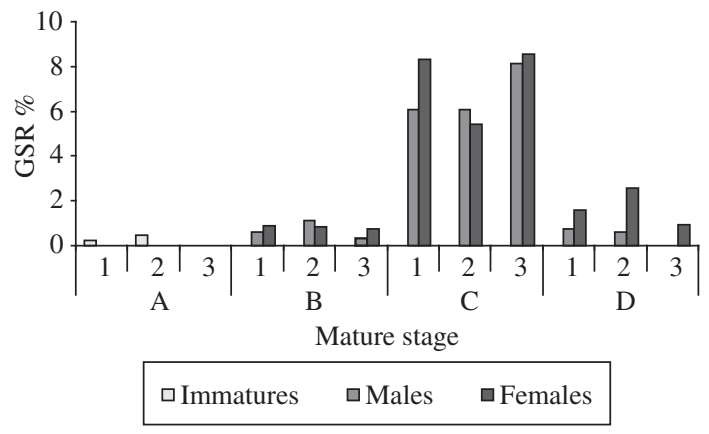

Figure 2. Gonadossomatic relation (GSR) for immatures, males, and females of Brycon opalinus at each stage of maturity (A: immature, B: maturing, C: mature, and D: spent) at the three collection points (1. Paraibuna; 2. Ipiranga; and 3. Grande). 
Table 1. Mean values of the gonadossomatic relation (GSR) for immatures, males, and females of Brycon opalinus in each stage of maturity at the three collection points (Paraibuna, Ipiranga, and Grande).

\begin{tabular}{|c|c|c|c|c|}
\hline \multicolumn{5}{|c|}{ Stage A (immatures) } \\
\hline & \multicolumn{2}{|r|}{$\mathbf{N}$} & \multicolumn{2}{|c|}{ GSR (min.-max.) } \\
\hline Paraibuna & \multicolumn{2}{|r|}{01} & \multicolumn{2}{|c|}{0,22} \\
\hline Ipiranga & \multicolumn{2}{|r|}{01} & \multicolumn{2}{|c|}{0,22} \\
\hline Grande & \multicolumn{2}{|r|}{-} & \multicolumn{2}{|c|}{-} \\
\hline Total & \multicolumn{2}{|r|}{02} & \multicolumn{2}{|c|}{$0,35(0,22-0,47)$} \\
\hline \multicolumn{5}{|c|}{ Stage B (in maturation) } \\
\hline & \multicolumn{2}{|r|}{ Males } & \multicolumn{2}{|c|}{ Females } \\
\hline & $\mathbf{N}$ & GSR (min.-max.) & $\mathbf{N}$ & GSR (min.-max.) \\
\hline Paraibuna & 11 & $0.63(0.18-1.47)$ & 18 & $0.87(0.47-1.42)$ \\
\hline Ipiranga & 15 & $1.11(0.14-4.72)$ & 38 & $0.83(0.25-2)$ \\
\hline Grande & 01 & 0.32 & 03 & $0.76(0.43-1.11)$ \\
\hline Total & 27 & $0.89(0.14-4.72)$ & 59 & $0.84(0.25-2)$ \\
\hline \multicolumn{5}{|c|}{ Stage C (mature) } \\
\hline & \multicolumn{2}{|r|}{ Males } & \multicolumn{2}{|c|}{ Females } \\
\hline & $\mathbf{N}$ & GSR (min.-max.) & $\mathbf{N}$ & GSR (min.-max.) \\
\hline Paraibuna & 15 & $6.07(1.05-9.87)$ & 42 & $8.32(1.21-17.19)$ \\
\hline Ipiranga & 16 & $6.09(3.56-9.93)$ & 11 & $5.4(2.23-11.91)$ \\
\hline Grande & 03 & $8.13(6.4-10.88)$ & 15 & $8.54(2.36-16.85)$ \\
\hline Total & 34 & $6.36(1.05-10.88)$ & 68 & $8.08(1.21-17.19)$ \\
\hline \multicolumn{5}{|c|}{ Stage D (spent) } \\
\hline & \multicolumn{2}{|r|}{ Males } & \multicolumn{2}{|c|}{ Females } \\
\hline & $\mathbf{N}$ & GSR (min.-max.) & $\mathbf{N}$ & GSR (min.-max.) \\
\hline Paraibuna & 01 & 0.76 & 10 & $1.59(0.71-3.69)$ \\
\hline Ipiranga & 01 & 0.62 & 11 & $2.58(0.92-8.32)$ \\
\hline Grande & - & & 03 & $0.94(0.66-1.18)$ \\
\hline Total & 02 & $0.69(0.62-0.76)$ & 24 & $1.97(0.66-8.32)$ \\
\hline
\end{tabular}

During the course of the year, the GSR of mature males and females was always high, with peaks in spring and winter for females, and in autumn for males (Figure 3).

In spring, the GSR of mature females was above $10 \%$ and that of mature males was above $6 \%$. In summer, the GSR fell, with males showing values above those of females in the Paraibuna and Ipiranga rivers. In the autumn, the GSR increased for both sexes, but was still higher for the males. In winter the GSR of the males fell and for the females of the Paraibuna River returned to above $10 \%$ (Figure 4).

An analysis of the Kolmogorov-Smirnov test (Vanzolini, 1993) applied to the frequency distributions of total-length classes for males and females revealed a difference between these distributions $\left(\chi^{2}<0.05\right)$. The analysis of total-length classes of mature males and females showed that the GSR was always above 5\%. The highest values were obtained for the classes of 28 to $32 \mathrm{~cm}$ and of 32 to $36 \mathrm{~cm}$ for males and females, respectively. The smallest length class $(16$ to $20 \mathrm{~cm}$ ) contained only males, and the largest ( 32 to $36 \mathrm{~cm}$ ) only females,

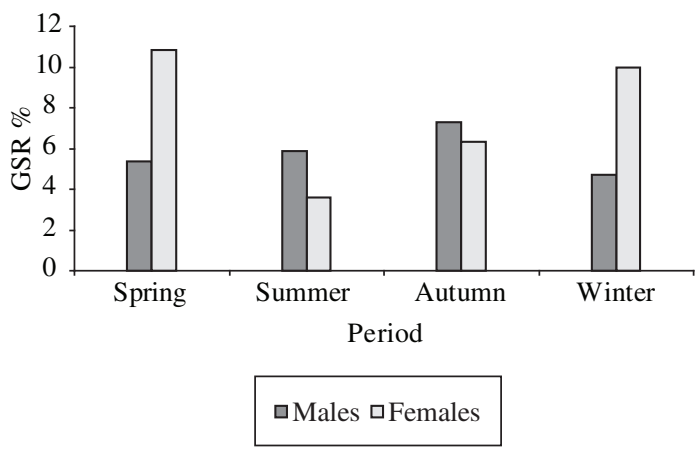

Figure 3. Gonadossomatic relation (GSR) for mature males and females of Brycon opalinus in each season of the year.

evidencing the sexual dimorphism of males and females (Figure 5).

\section{Discussion}

The larger size of mature females of Brycon opalinus in relation to males (sexual dimorphism) appears to be very common in fishes. This occurs because of the pres- 
sures for greater fecundity of the females (Pauly, 1994; Vazzoler, 1996), because the reproductive success of females increases directly with size (Conover, 1984).

The GSR shown by mature females of Brycon opalinus was much lower than that of Brycon orbignyanus

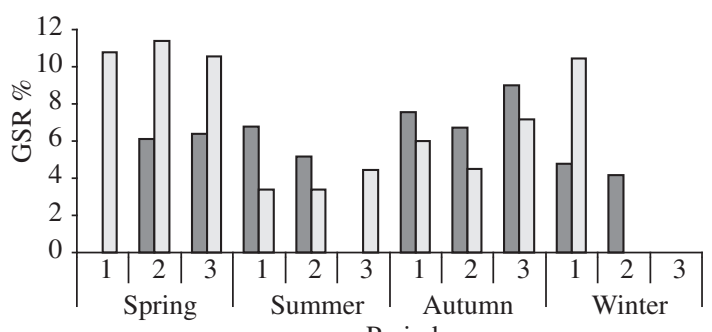

$$
\text { Period }
$$

$\square$ Males $\square$ Females

Figure 4. Gonadossomatic relation (GSR) for mature males and females of Brycon opalinus in each season of the year and at the three collection points (1. Paraibuna, 2. Ipiranga, and 3. Grande).

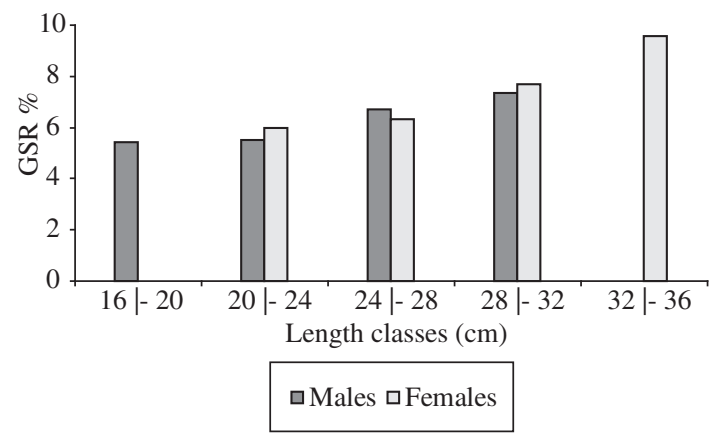

Figure 5. Gonadossomatic relation (GSR) for mature males and females of Brycon opalinus in the total-length classes.
(Valenciennes, 1850) and Brycon hilarii (Valenciennes, 1850) (Table 2); nevertheless, in B. opalinus, part of the population had mature gonads all year long. This may be related to a longer reproductive period and to the lack of seasonal long-distance migration.

The values of the GSR may vary widely among species. In 80 teleost species in the Upper Paraná River, the GSR for females varied from 2.94 to $28.39 \%$, with $83.75 \%$ of the species showing a maximum GSR above 7, 48.75\% above $12 \%$, and 10 above $22 \%$ (Vazzoler, 1996).

In relation to $B$. opalinus, the GSR of mature males reached higher values in Brycon cephalus (Günther, 1869), B. orbignyanus and B. hilarii, as reported in the literature (Table 2). These values are higher than those of other species which have sperm competition during mating. In these species, the highest values of the GSR for females varied from 6 to $9 \%$, and for males from 0.9 to $3.32 \%$ (Treasurer, 1990; Gonçalves and Almada, 1997; Neat et al., 2003b).

Fishes show a greater variation of intensity in sperm competition than does any other animal group (Stockley et al., 1997; Taborsky, 1998). In these cases, sperm production, the size of the testicles, and the energy costs are higher than in species in which sperm competition does not occur (Shapiro et al., 1994; Tomkins and Simmons, 2002; Neat et al., 2003b; Zbinden et al., 2003). Sperm competition is common in fishes with external fertilization, because of the high predictability of the moment of liberation of the oocytes, and also because it is very difficult for a male to monopolize a female (Birkhead, 1995).

Sperm production is an energy-expensive process, and this extra production must offer an adaptive advantage (Ota et al., 1996). When females mate with more than one male, selection must favor males with larger

Table 2. Data from the literature and from the present investigation on GSR of Brycon species.

\begin{tabular}{|c|c|c|c|c|}
\hline Authors & $\begin{array}{c}\text { Species } \\
\text { (condition) }\end{array}$ & Sex & $\begin{array}{r}<\text { GSR\% } \\
\text { (season) }\end{array}$ & $\begin{array}{l}\text { > GSR\% } \\
\text { (season) }\end{array}$ \\
\hline Zaiden (2000) & Brycon hilarii (captive) & Males & $\begin{array}{c}<0.1 \\
\text { Autumn } \\
\text { Winter }\end{array}$ & $\begin{array}{c}1.4 \\
\text { Spring } \\
\text { Summer }\end{array}$ \\
\hline Zaiden (2000) & Brycon hilarii (captive) & Females & $\begin{array}{c}0.78 \\
\text { Autumn }\end{array}$ & $\begin{array}{c}22 \\
\text { Spring }\end{array}$ \\
\hline Romagosa et al. (2000) & Brycon cephalus (captive) & Males & $\begin{array}{c}0.019 \\
\text { Autumn }\end{array}$ & $\begin{array}{c}1.9 \\
\text { Spring }\end{array}$ \\
\hline Carvalho and Urbinati (2005) & Brycon cephalus (captive) & Females & $\begin{array}{c}0.06 \\
\text { Winter }\end{array}$ & $\begin{array}{c}3.7 \\
\text { Summer }\end{array}$ \\
\hline Zaiden (1997) & Brycon orbignyanus (captive) & Males & $\begin{array}{c}0.03 \\
\text { Autumn }\end{array}$ & $\begin{array}{c}1.46 \\
\text { Spring }\end{array}$ \\
\hline Vazzoler (1996) & Brycon orbignyanus (wild) & Females & & $\begin{array}{c}20.57 \\
\text { Spring }\end{array}$ \\
\hline Present work & Brycon opalinus (wild) & Males & $\begin{array}{c}0.32 \\
\text { Winter }\end{array}$ & $\begin{array}{c}8.13 \\
\text { Autumn }\end{array}$ \\
\hline Present work & Brycon opalinus (wild) & Females & $\begin{array}{c}0.76 \\
\text { Summer }\end{array}$ & $\begin{array}{c}8.54 \\
\text { Spring } \\
\end{array}$ \\
\hline
\end{tabular}


and high-quality testicles and ejaculations, because the importance of competition is reflected in the investment in testicular tissue (Birkhead, 1995). Success in competition for males directly affects the number of descendents, and polyandry for females increases the quality and genetic diversity of the descendents (Parker, 1970; Yasui, 1998).

The mature testicles of Brycon opalinus were always very large, occupying about $1 / 3$ of the abdominal cavity. Possession of large testicles in relation to body size (GSR) is an indicator of species with a mating system in which the females mate with more than one male (Taborsky, 1998; Pyron, 2000). With the increase in sperm competition, the GSR and the number of spermatozoa increase and the size of the spermatozoa decrease (Ball and Parker, 1996; Stockley et al., 1997; Arnaud et al., 2001). After they are diluted (liberated), the spermatozoa are mobile for only $\pm 2 \mathrm{~mm}$ in freshwater fishes (Ota et al., 1996), and normally have a short lifespan with high mobility (Gage et al., 1998).

Brycon opalinus spawns in small streams with variable current velocity and turbulence (Villani J. P., pers. com.). Water turbulence negatively influences the fertilization rate, which must be compensated by the increase in sperm production. Under these conditions, selection must favor females which mate with males that liberate large amounts of sperm (Shapiro et al., 1994). In populations of Salaria fluviatilis (Asso, 1801) in rivers and lakes, there were differences in the investment in sperm. In the populations in rivers, there was greater investment in sperm, and this is related to losses of sperm during fertilization because of the greater flow and turbulence of the water (Neat et al., 2003a).

Another characteristic that evidences spawning of Brycon opalinus in locales with water currents is the concentration of sperm. This species has a spermatic concentration of $50 \times 10^{6} / \mathrm{mm}^{3}$ (Narahara et al., 2002). This is twice as high as that of Brycon insignis (Steindachner, 1876) which is $24.76 \times 10^{6} / \mathrm{mm}^{3}$. B. insignis incubates its eggs in backwaters or in floodplain lakes (AndradeTalmelli et al., 2001). The greater the concentration of spermatozoa around the egg mass, the more efficient will be the fertilization (Shapiro et al., 1994). Because of this, a higher spermatic concentration is expected in fish in lotic waters. The characteristics of the medium, such as internal or external fertilization and the velocity and salinity of the water, alter the adaptive requirements for the concentration, size, and longevity of the spermatozoa (Stockley et al., 1997).

Different locales afford different ecological niches, predation regimes, and population densities. These differences lead to evolutionary responses in the fishes' life histories, in their adaptations for exploiting resources, avoiding predation, and reproduction (Neat et al., 2003a).

The GSR of mature males of B. opalinus evidences the great development of the testicles, because of sperm competition (among several males) and the dilution of the ejaculate by water currents during the spawning processes. In this context, it was expected that the sexratio would tend toward males; however, the contrary occurred. The values of the sex-ratio may mask what actually occurs during mating. For example, Engraulis ringens (Jenyns, 1842) has a sex-ratio close to 1; however, females ready to spawn appear to attract males, forming "spawning schools," with a strong predominance of males, and these schools segregate themselves from the normal school during the night (Vazzoler, 1996). According to Conover (1984), Menidia menidia (Linnaeus, 1766) showed a sex-ratio of 10 males per female during spawning; both sperm competition and successive mating of the males with different females occurred. Nevertheless, the sex-ratio for this species was one male per female, or tended slightly toward females in non-breeding schools.

In Brycon opalinus, the size of the testicles, besides indicating sperm competition, may be related not only to increased production, but also to increased accumulation of sperm. These characteristics developed because of the evolutionary pressures of successive mating with different females at any season of the year (long reproduction), thus explaining the higher sex-ratio for females. Further, the collections were made over only a single year, which may have led to errors in analyzing the sexratio, because the ratio may vary in different seasons (Korpelainen, 1990).

The mechanisms of sex determination in fishes are still little explored. Environmental factors cannot be discarded as possible variables that influence the sex-ratio of the species. Sex determination in teleosts may, in many cases, be non-genetic (Strussmann et al., 1996), because sex determination by environmental factors appears to be more common than expected in fishes (Korpelainen, 1990; Romer and Beisenherz, 1996).

In fishes, sex determination by environmental factors can occur through temperature, $\mathrm{pH}$, salinity, light, water quality, and nutrition (Korpelainen, 1990). Environmental sex determination may act mainly in species which exhibit sexual dimorphism (females larger than males), sperm competition, a prolonged breeding season, and early sexual maturity (Conover, 1984; Korpelainen, 1990). This kind of sex determination must be favored when these factors differentially improve the fitness of male or female young, and also in environments that do not fluctuate excessively (Charnov and Bull, 1977; Conover and Kynard, 1981; Conover and Heins, 1987).

The mechanisms of sex determination in Brycon opalinus are still unknown; however, this species has all the prerequisites for environmental sex determination. This is corroborated by its reproductive characteristics, such as sperm competition, sexual dimorphism, and the long reproductive period.

Given the growing recognition of the effects of environmental factors on sex determination, the possible effects of global climate changes and of the changes in temperature induced by humans in localized environ- 
ments merit more thorough investigation (Craig et al., 1996).

Acknowledgments - The authors wish to thank FAPESP (proc. 03/05696-1) for financial support, Cotec (proc. 40.673/03), IBAMA (aut. 055/2003), and especially Mr. J. P. Villani (Director of the Núcleo Santa Virgínia-PESM) for making it possible to carry out this research.

\section{References}

ANDRADE-TALMELLI, EF., KAVAMOTO, EM. and FENERICH-VERANI， N., 2001. Características seminais da piabanha, Brycon insignis (Steindachner, 1876), após estimulação hormonal. Bol. Inst. Pesca, vol. 27, no. 2, p. $149-154$.

ARNAUD, L., HAUBRUGE, E. and GAGE, MJG., 2001. Sperm size and number variation in the red flour beetle. Zool. $J$. Linn. Soc., vol. 133, no. 3, p. 369-375.

BALL, MA. and PARKER, GA., 1996. Sperm competition games: external fertilization and "adaptive" infertility. J. Theor. Biol., vol. 180, no. 2, p. 141-150.

BIRKHEAD, TR., 1995. Sperm competition: evolutionary causes and consequences. Reprod. Fertil. Dev., vol. 7, no. 4, p. $755-775$.

BRAGA, FMS., 1990. Aspectos da reprodução e alimentação de peixes comuns em um trecho do rio Tocantins entre Imperatriz e Estreito, Estados do Maranhão e Tocantins, Brasil. Rev. Bras. Biol., vol. 50, no. 3, p. 547-558.

CARVALHO, EG. and URBINATI, EC., 2005. Crescimento, desenvolvimento gonadal e composição muscular de matrinxã (Brycon cephalus) submetidos à restrição alimentar e realimentação durante um ano. Ciência Rural, vol. 35, no. 4, p. 897-902.

CHARNOV, EL. and BULL, J., 1977. When is sex environmentally determined? Nature, vol. 266, no. 5605, p. $828-830$.

CONOVER, DO., 1984. Adaptive significance of temperaturedependent sex determination in a fish. Am. Nat., vol. 123, no. 3, p. 297-313.

CONOVER, DO. and HEINS, SW., 1987. Adaptive variation in environmental and genetic sex determination in a fish. Nature, vol. 326, no. 6112, p. 496-498.

CONOVER, DO. and KYNARD, BE., 1981. Environmental sex determination: interaction of temperature and genotype in a fish. Science, vol. 213, p. 577-579.

CRAIG, JK., FOOTE, CJ. and WOOD, CC., 1996. Evidence for temperature-dependent sex determination in sockeye salmon (Oncorhynchus nerka). Can. J. Fish. Aquat. Sci., vol. 53, no. 1, p. 141-147.

DENNY, MW. and SHIBATA, MF., 1989. Consequences of surf-zone turbulence for settlement and external fertilization. Am. Nat., vol. 134, no. 6, p. 859-889.

GAGE, MJG., STOCKLEY, P. and PARKER, GA., 1998. Sperm morphometry in the Atlantic salmon. J. Fish Biol., vol. 53, no. 4, p. $835-840$.

GONÇALVES, EJ. and ALMADA, VC., 1997. Sex differences in resource utilization by the peacock blenny. J. Fish Biol., vol. 51, no. 3, p. 624-633.
GROSS, MR., 1985. Disruptive selection for alternative life histories in salmon. Nature, vol. 313, no. 5997, p. 47-48.

-, 1996. Alternative reproductive strategies and tactics: diversity within sexes. Tree, vol. 11, no. 2, p. 92-98.

KORPELAINEN, H., 1990. Sex ratios and conditions required for environmental sex determination in animals. Biol. Rev., vol. 65 , no. 02 , p. $147-184$.

LEVITAN, DR., 2005. Sex-specific spawning behavior and its consequences in an external fertilizer. Am. Nat., vol. 165, no. 6, p. 682-694.

LEVITAN, DR. and PETERSEN, C., 1995. Sperm limitation in the sea. TREE, vol. 10 , no. 6 , p. 228-231.

NARAHARA, MY., ANDRADE-TALMELLI, EF., KAVAMOTO, ET. and GODINHO, HM., 2002. Reprodução induzida da pirapitinga do sul, Brycon opalinus, mantida em condições de confinamento. Rev. Bras. Zootec., vol. 31, no. 3, p. $1070-1075$.

NEAT, FC., LENGKEEK, W., WESTERBEEK, EP., LAARHOVEN, B. and VIDELER, JJ., 2003a. Behavioural and morphological differences between lake and river populations of Salaria fluviatilis. J. Fish Biol., vol. 63, no. 2, p. 374-387.

NEAT, FC., LOCATELLO, L. and RASOTTO, MB., $2003 \mathrm{~b}$. Reproductive morphology in relation to alternative male reproductive tactics in Scartella cristata. J. Fish Biol., vol. 62, no. 6 , p. 1381-1391.

OTA, D., MARCHESAN, M. and FERRERO, EA., 1996. Sperm release behaviour and fertilization in the grass Gob. J. Fish Biol., vol. 49, no. 2, p. 246-256.

PARKER, GA., 1970. Sperm competition and its evolutionary consequences in the insects. Biol. Rev., vol. 45, p. 525-567.

PAULY, D., 1994. On the sex of fish and the gender of scientists. A collection of essays in fisheries science. Chapman \& Hall. Fish and Fisheries Series 14, 250p.

PRADO, CPA. and HADDAD, CFB., 2003. Testes size in leptodactylid frogs and occurrence of multimale spawning in the genus Leptodactylus in Brazil. J. Herpet., vol. 37, no. 2, p. 354-362.

PYRON, M., 2000. Testes mass and reproductive mode of minnows. Behav. Ecol. Sociobiol., vol. 48, no. 2, p. 132-136.

ROMAGOSA, E., NARAHARA, MY., AYROZA, LMS., BORELLA, MI. and FENERICH-VERANI, N., 2000 Reproductive cycle of male matrinxã, Brycon cephalus (Günther, 1869) (Teleostei: Characidae). Braz. J. Morphol., vol. 17 , no. 2000 , p. 101-105.

ROMER, U. and BEISENHERZ, W., 1996. Environmental determination of sex in Apistogramma (Cichlidae) and two other freshwater fishes (Teleostei). J. Fish Biol., vol. 48, no. 4, p. 714-725.

SHAPIRO, DY., MARCONATO, A. and YOSHIKAWA, T., 1994. Sperm economy in a coral reef fish, Thalassoma bifasciatum. Ecology, vol. 75, no. 5, p. 1334-1344.

SRIVASTAVA, SJ. and SINGH, R., 1994. Seasonal changes in the testes of a freshwater murrel, Channa punctatus. Naturalia, vol. 19, no. 1, p. 119-130.

STOCKLEY, P., GAGE, MJG., PARKER, GA. and MOLLER, AP., 1997. Sperm competition in fishes: the evolution of testis 
size and ejaculate characteristics. Am. Nat., vol. 149, no. 6, p. 933-954.

STRUSSMANN, CA., MORIYAMA, S., HANKE, EF., COTA, JCC. and TAKASHIMA, F., 1996. Evidence of thermolabile sex determination in pejerrey. J. Fish Biol., vol. 48, no. 4, p. 643-651.

TABORSKY, M., 1998. Sperm competition in fish: "bourgeois" males and parasitic spawning. TREE, vol. 13, no. 6, p. 222-227.

TOMKINS, JL. and SIMMONS, LW., 2002. Measuring relative investment: a case study of testes investment in species with alternative male reproductive tactics. Anim. Behav., vol. 63, no. 5, p. 1009-1016.

TREASURER, JW., 1990. The annual reproductive cycle of pike, Esox lucius, in two Scottish lakes. J. Fish Biol., vol. 36, no. 1, p. 29-46.

VANZOLINI, PE., 1993. Métodos estatísticos elementares em sistemática zoológica. São Paulo-SP, Ed. HUCITEC., 130p.

VAZZOLER, AEAM., 1996. Biologia da reprodução de peixes teleósteos: Teoria e Prática. Maringá-PR, Nupelia, 169p.
VIEITES, DR., NIETO-ROMÁN, S., BARLUENGA, M., PALANCA, A., VENCES, M. and MEYER, A., 2004. Postmating clutch piracy in an amphibian. Nature, vol. 431, no. 7006 , p. $305-308$.

YASUI, Y, 1998. The "genetic benefits" of female multiple mating reconsidered. TREE, vol. 13, no. 6, p. 246-250.

ZAIDEN, SF., 1997. Estrutura testicular da piracanjuba Brycon orbignyanus (Valenciennes, 1849) (Pisces, Characidae), nos vários estádios do ciclo sexual. 78p. (Dissertação de Mestrado) - UNESP, Centro de Aqüicultura, Jaboticabal, SP.

-, 2000. Morfologia gonadal e metabolismo energético da piraputanga Brycon hilarii (Cuvier e Valenciennes, 1849) (Pisces, Characidae), em cativeiro, durante o ciclo reprodutivo anual. 152p. (Tese de Doutorado) - UNESP, Centro de Aqüicultura, Jaboticabal, SP.

ZBINDEN, M., LARGIADER, CR. and BAKKER, TCM., 2001. Sperm allocation in the three-spined stickleback. J. Fish Biol., vol. 59, no. 5, p. 1287-1297.

ZBINDEN, M., MAZZI, D., KUNZLER, R., LARGIADER, CR. and BAKKER, TCM., 2003. Courting virtual rivals increase ejaculate size in sticklebacks (Gasterosteus aculeatus). Behav. Ecol. Sociobiol., vol. 54, no. 3, p. 205-209. 